\title{
Medical Geology and Health: An Approach to Address Diseases Related to Natural Environment-Reviewing the Ghanaian Situation
}

\author{
${ }^{1}$ EmmanuelArhin, ${ }^{1}$ Raymond Kazapoe and ${ }^{1}$ Abu Mahamuda \\ ${ }^{1}$ University for Development Studies, P. O. Box 24, Navrongo, Ghana \\ Corresponding author: Raymond.Kazapoe@uds.edu.gh
}

\begin{abstract}
Inadequate data linking geology and health in Developing Countries contributes immensely to the challenges to identify sources and causes of many of the emerging diseases. Deficiencies and toxicities of trace elements generally impact human and animal health. The review of the geology of Ghana suggests the presence of oxides and sulphide minerals that are released into the natural environment during the geological process of weathering which introduce both essential and, potentially harmful elements. Of great concern is the fact that majority of the Ghanaian population eat locally cultivated food and expect to be nourished from the diet. Furthermore, archived reports on Ghana rural drinking water indicates most of the aquifers are enriched in As and F while deficient in Mg. Medical geology, the emerging discipline that attempts to address the environmental health issues emanating from geological processes is known in developed nations but not much of its activities are recognized in Ghana. This review has identified the concentrations of a number of elements in different geological settings and have linked these concentrations with health issues. There is therefore a need for medical geologists to work together with other disciplines to devise preventive as well as mitigative techniques in addressing many geology related health issues in Ghana.
\end{abstract}

Keywords: Geological process, geological materials, trace elements, environmental health

\section{Introduction}

Medical geology, formerly referred to as Geo-medicine, is an interdisciplinary field of study that examines relationships between geological processes in the oxidising environments and their geospatial impacts on human and animal health. The acts of exploiting earth resources facilitate the dispersion of toxic and essential elements in the natural environment. The 
exposure of these elements and pathways by which they get into the human physiology often leads either to good or adverse health outcomes. Recent medical geology research shows the links between the natural environment and public health. The recognition of this fact is demonstrated by geological processes that release both toxic and essential elements in the natural environment which subsequently affect human and animal health. The concentration of the elements released through geological processes is in the purview of geochemistry. The concentrations and assemblages of these elements vary in in the atmosphere, lithosphere and hydrosphere and as a result, plants, animals and humans are exposed to them one way or the other. This review seeks to highlight the impact of some trace elements on human health and significantly reveal the role of earth science can play in supporting public health protection. This study also shows the direct health impacts related to degree of saturation of specific elemental uptake from the environment.

\subsection{Regional Geology of Ghana}

The geology of Ghana comprises a wide array of rocks which presents a distinct variability in earth materials (Fig. 1).

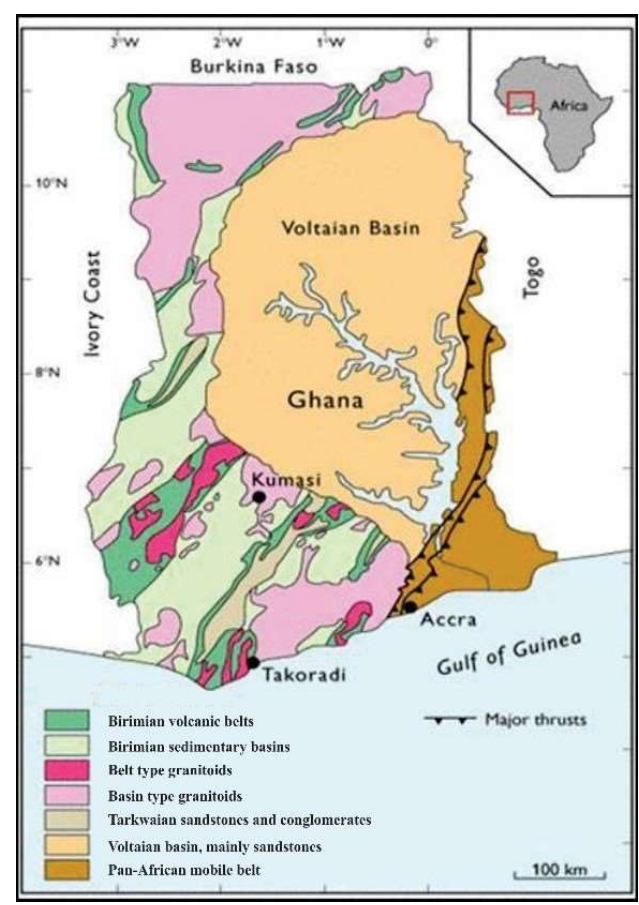

Figure 1: Geological Map of Ghana, Source Ghana Geological Survey.

The Paleoproterozoic Birimian compose the Western units, found at the eastern margin of the West African Craton. The Birimian in Ghana is characterized by NE-SW trending greenstone belts separated by sedimentary basins (Dampare et al., 2008). Both the belts and the basins are 
intruded by a wide variety of granitic rocks that have varying minerarologies (Abitty et al., 2016). The Pan African mobile belt occupies the southeastern domain of the country and is composed mainly of the sedimentary Buem structural units, the considerably more metamorphosed Togo structural unit and the predominantly metamorphic rocks of the Dahomeyan basement units (Nude et al., 2015). The Neoproterozoic Voltaian sediments situated on the south-eastern margin of the West African Craton, covers an estimated area of $103,600 \mathrm{~km}^{2}$, almost a third of the area of Ghana. The main rock types of the Voltaian include sandstones, shales, mudstones and conglomerates. The rocks of the coastal sedimentary basins and the tertiary to Recent deposits are predominantly sedimentary units (Kesse, 1980).

The variability of these geological domains suggests that a wide range of minerals and elements are potentially being leeched into the natural environment. However, since the modal composition of the minerals in a particular rock may not be isotropic, there is a high possibility that the concentration of a particular mineral or element may fluctuate in the same rock type but at different locations.

\subsection{Geochemistry of disease-causing elements in the environment}

Geologists define rocks as an aggregate of minerals (Arhin et al., 2017). The distributions and concentrations of these elements in the environment may be affected by surface conditions but their primary source could either be geogenic and/or anthropogenic in nature. DzigbodiAdjimah (1993) and Kesse (1980) report of chalcophile elements and their association with gold mineralization in the Greenstone Belts of the Birimian of Ghana. The Birimian Greenstone Belt occurs in seven different areas covering about one-third of Ghana's total landmass. (Norman et al., 2001) found gold and arsenic proportions in these volcanic belts to be over 10 times the average crustal abundance. Other researchers have also reported arsenic concentration of about $2 \mathrm{wt} . \%$ and 542-1752ppm in pyrite and arsenopyrite in Prestea and Obuasi areas of Southwest Ghana in hydrothermal veins (Bempah et al., 2013) where gold has been mined for many years. Similarly, in northern Burkina Faso soil samples analyzed for gold anomalies within the vicinity of Proterozoic Birimian rocks showed arsenic concentrations above 25 ppm in pyrite, and chalcopyrite hosted in quartz veins. (Tescult, 1999; Smedley and Kinniburgh, 2002) It is thus safe to conclude that most minerals in the Birimian rocks contain arsenic, a known cancer-causing element. Over exposure to arsenic and other chalcophile elements has been linked with many medical conditions, some of which may be fatal due to prolonged exposure. Table 1 shows worldwide Arsenic concentrations in selected oxides and sulphide minerals. The listed minerals are found associated with rocks in Ghana. 
Table 1 Arsenic concentration ranges $(\mathrm{mg} / \mathrm{kg})$ in sulphide and oxide minerals in worldwide rocks.

\begin{tabular}{lll}
\hline \multicolumn{1}{c}{ Mineral } & Minimum (mg/kg) & Maximum $(\mathbf{m g} / \mathbf{k g})$ \\
Sulphide Minerals & & \\
Pyrite & 100 & 120000 \\
Pyrrhotite & 5 & 100 \\
Marcasite & 20 & 276000 \\
Galena & 5 & 10000 \\
Sphalerite & 5 & 17000 \\
Chalcopyrite & 10 & 5000 \\
Oxide Minerals & & \\
Haematite & $\leq 186000$ & \\
Iron (III) oxyhydroxides & $\leq 76000$ & \\
Magnetite & & \\
Maghemite & & \\
\hline
\end{tabular}

Fluoride is another element which brings a lot of health problems such as fluorosis appears to be enriched in most rocks in Ghana. Investigations in the Upper East region of Ghana reveals that water from aquifers within the Birimian metavolcanics and metasediments along with the associated intrusive rocks have elevated fluoride concentrations that exceed the of WHO guideline values as presented in Table 2.

Table 2 Variation of fluoride concentration $(\mathrm{mg} / \mathrm{l})$ in drinking water draining the Birimian rocks in Upper East region of Ghana. 


\begin{tabular}{|c|c|c|c|c|c|}
\hline Geology & $\mathrm{n}$ & Minimum & Mean & Maximum & $\begin{array}{l}\%>\text { Accepted } \\
\text { Value }\end{array}$ \\
\hline Bongo \& Tongo Granite & 46 & 0.09 & 1.88 & 4.4 & 54 \\
\hline Sekoti Granodiorite & 8 & 0.86 & 1.56 & 3.2 & 38 \\
\hline $\begin{array}{l}\text { Irimian granodiorite, } \\
\text { adamellite and gneiss }\end{array}$ & 85 & 0.15 & 0.72 & 3.6 & 13 \\
\hline $\begin{array}{lr}\text { Birimian } & \text { greenstone } \\
\text { (metavolcanic } & \text { and } \\
\text { metasediments) } & \end{array}$ & 46 & 0.13 & 0.55 & 3.6 & 9 \\
\hline
\end{tabular}

Source: Apambire et al.,

\subsection{Mitigation Plan using multidisciplinary approach}

Preventing the outbreak of health-related issues emanating from the geological processes that directly contaminate media such as soils and water depend on the ability of identifying the pollution hotspots of the hazardous elements. From a medical geology perspective, the source of these elements whether essential or toxic is related to the composition of the geological material but its dispersion in the environment is mainly facilitated by anthropogenic activities. Table 2 and Table 3 show the percentage exceedances of specific minerals above the WHO guideline values found in Ghanaian water and soil samples.

Table 3 Percentage exceedances of elements with health implications in Ghanaian waters compared with WHO guideline values (Smedley et al. 2002).

\begin{tabular}{lllllll}
\hline & $\begin{array}{l}\text { WHO } \\
\text { Accepted } \\
\text { Element } \\
\text { values } \\
(\mathrm{mg} / \mathrm{l})\end{array}$ & $\begin{array}{l}\text { Max- } \\
\text { Measured } \\
(\mathrm{mg} / \mathrm{l})\end{array}$ & $\mathrm{n}>$ WHO & $\begin{array}{l}\text { \% Exceeding } \\
\text { Accepted } \\
\text { value }\end{array}$ & $\begin{array}{l}\text { Accepted } \\
\text { Value }\end{array}$ & \\
& & & & & & \\
\hline F & 0.5 & 4.0 & 185 & 43 & 23.2 & Skeletal Fluorosis \\
U & 0.002 & 0.032 & 185 & 18 & 9.7 & Kidney Damage \\
\hline
\end{tabular}




\begin{tabular}{|c|c|c|c|c|c|c|}
\hline NO3-N & 11.3 & 33.0 & 185 & 12 & 5.9 & $\begin{array}{l}\text { Transform hemoglobin to } \\
\text { methemoglobin that lacks } \\
\text { the oxygen-carrying ability } \\
\text { of hemoglobin }\end{array}$ \\
\hline As & 0.01 & 0.434 & 185 & 5 & 2.7 & $\begin{array}{l}\text { Cancer, kidney, bladder } \\
\text { diseases and skin lesions. }\end{array}$ \\
\hline B & 0.5 & 0.13 & 185 & $\mathbf{0}$ & $\mathbf{0}$ & \\
\hline Ba & 0.7 & 0.59 & 185 & 0 & 0 & \\
\hline Cd & 0.003 & 0.0002 & 185 & $\mathbf{0}$ & $\mathbf{0}$ & \\
\hline $\mathrm{Cr}$ & 0.05 & 0.010 & 185 & $\mathbf{0}$ & $\mathbf{0}$ & \\
\hline $\mathbf{C u}$ & 2.00 & 0.030 & 185 & $\mathbf{0}$ & $\mathbf{0}$ & \\
\hline Mn & 0.50 & 0.406 & 185 & $\mathbf{0}$ & $\mathbf{0}$ & \\
\hline Mo & 0.07 & 0.015 & 185 & $\mathbf{0}$ & $\mathbf{0}$ & \\
\hline $\mathbf{N i}$ & 0.02 & 0.004 & 185 & $\mathbf{0}$ & 0 & \\
\hline $\mathbf{P b}$ & 0.01 & 0.004 & 185 & $\mathbf{0}$ & 0 & \\
\hline Sb & 0.005 & 0.0017 & 185 & $\mathbf{0}$ & 0 & \\
\hline
\end{tabular}

Only the elements that have linked to environmental health problems have been listed. The reported concentrations presented in the Table are from studies carried out in Ghana by some independent researchers (Smedley and Kinniburgh, 2002; Apambire et al., 1997) and thus suggest an urgent need to undertake further investigations as low concentrations of elements such as $\mathrm{Cu}, \mathrm{Se}, \mathrm{Zn}$ and I may result in nature deficit disorders. Similarly, toxicities of $\mathrm{As} \mathrm{Hg}$, $\mathrm{Cd}, \mathrm{Pb}$ and $\mathrm{F}$ may come with their related health issues. Controlling the effects of deficiency 
and toxicity of these elements require an understanding of their sources, exposure and pathways.

\subsection{Human Exposure and Pathway}

Trace elements can get into the human system via ingestion, inhalation and dermal contact. In Ghana majority of food consumed are produced locally. Drinking waters often are from groundwater and surface water (Ghana Statistical Service, 2010) These trace elements are unintentionally taken up in crops and water that have excess concentrations of some of the toxic elements. It has long been said that 'we are what we eat'. However, based on the mode by which humans get exposed to pollutants that subsequently affect our health, makes it proper to say that 'we are what we eat, drink and breathe'. Additionally, the perennial dust accompanying the harmattan winds carry along pathogens and toxic trace elements that are blown over the West African sub-region from the Sahara. The strong dust is known generally to have been blown from weathered materials of the underlying rocks and contain mixture of pathogens, fine dust and hazardous trace elements that causes respiratory infections including asthma. This dust pollutes surface water and can cause diarrhoea and other water-borne illnesses if the polluted water is not properly treated before it is used for domestic purposes (Leary, 1986; Derry et al.,1990). There are so many other health-related issues linked to the inhalation of dust which have not been investigated. This aspect of medical geology investigation relative to disease patterns in Ghana receives very little attention. There seems to be no coordination among environmental earth scientists, medical researchers as well as the public health workers regarding medical geology. But on the contrary, for better diagnoses and treatment of dust related diseases demand an interdisciplinary approach based on the principles of environmental earth science and medicine.

Table 4 thus shows pathways of exposure to humans and animals. Apart from the few anthropogenic additions of the toxic and essential elements the sources of all these elements are geogenic. Appropriate analyses and correct treatments to environmental health related diseases can be arrived at if the source of the pollutant is known. To prevent outbreak of environmental health diseases and to obtain answers to many of the unexplained deaths this review intends to summarise and create awareness of some of the impacts of the natural environment on public health by trace elements using the available medical geology information in Ghana. It will also highlight the potential effectiveness of addressing the 
environmental health diseases if the country conducts regional geochemical survey to define the pollution hotspots to advance the interdisciplinary multi-element studies that will prevent trace elements-related-diseases through the re-emerging field of medical geology.

Table 4. Source exposure and pathways of trace elements to humans and animals from the surface environment.

\begin{tabular}{lllll}
\hline Source & Soil & Water & Food & Dust \\
\hline \multirow{2}{*}{ Exposure } & Essential and & Essential and & Essential and & Essential and \\
& Toxic Elements & Toxic Elements & Toxic Elements & Toxic Elements \\
Pathway & Ingestion, & Ingestion, & Ingestion & Inhalation, \\
& Dermal Contact & Dermal Contact & & Dermal Contact \\
\hline
\end{tabular}

\subsection{Identifying the potential pollutions sites}

The health registry of outpatient and inpatients of all health centres in Ghana record the geographical locations of all patients but this data is underutilised. Many of the environmental health problems can be resolved if geospatial disease maps can be generated from the health registry data. This probably can guide the environmental earth scientists to zoom in to problem areas in order to ascertain the source and causes of the prevalent diseases from both the medical and geological the standpoint. In addition, the rocks in Ghana have gone through different tectonic and evolutional episodes (Kesse, 1980; Leube et al., 1990) and styles of ancient mineralisation dating as far back as the Proterozoic age (Dzigbodi, 1993). The mineralisation particularly gold in the Birimian has been reworked and concentrated as paleoplacers in the adjacent Tarkwaian rock (Kesse, 1980). Through surface geological processes (e.g. weathering, leaching and eluviation) substantial quantities of elements, both essential and toxic elements and precious metals such as gold that were involved in ore forming processes, have been released into the environment and are hosted in sediments in water bodies. The gold mineralisation enrichments in gravels in recent sediments and in palaeochannels are referred to as auriferous gold deposits and these are sought for generally by the artisanal mine workers and alluvial gold mining companies. The operations of small-scale mining and ore-processing 
companies, the earthworks by the constructional companies coupled with the surface processes (both physical and chemical) occurring in the oxidizing environments facilitates the transportation of the essential and toxic elements, whose exposure to humans over short and long terms can sometimes lead to severe public health consequences (Arhin et al., 2016). The origins of the essential and toxic elements in the natural environment could be an attribute of either geogenic or anthropogenic sources (Armah et al., 2012; Nguyen et al., 2005). In general, the anthropogenic sources of these elements only constitute a constant source of pollution that can be controlled. On the contrary the geogenic sources require the understanding of the host sources, the mechanism of elemental release and the transporting pathways from the reducing environments to the oxidising environments in order to highlight the pollution hotspots. Knowledge of these factors can contribute to the development and implementation preventive/mitigation strategies that will limit the impact of harmful geological processes on human health. Based on the earth's structure relative to the differing geology in varying landscapes; the release of elements into soils, water and other environmental media from the underlying primary rocks can vary widely, even in uncontaminated environments. The different geological settings found in Ghana (Kesse, 1980; Griffis et al., 2002) suggests the likelihood of having different mineralogical and modal assemblage compositions. On the basis that these assertions are true, then dissimilarities in geochemical composition of rocks that constitute the parent materials of soils together with differences in soil-forming processes can result in a wide range of trace element concentrations in soils and in any environmental media (Alloway, 2013) discovered that contamination from many sources can often give rise to high concentrations of heavy metal loads that can could be toxic to the soil, and the organisms that live in it. (Alloway, 2013) cautioned that elements mobility depends on several factors including factors that affect the bioavailability of the elements (Simeonov et al., 2003). Many investigations have been conducted on anthropogenic contaminants of ecosystems across the globe with some emphases on the trace element concentrations and health with little regard to the geological process and materials. There are so many emerging diseases that the causes are suspected to have links with geological processes and materials. Therefore, to address the issues the natural environment is impacting on public health, there is a need for the medical geologist and the medical practitioners to work together in providing some valuable clues such as:

1. Source of these toxic elements;

2. Their concentrations in environmental/geologic media;

3. Pathways from the natural environment to the human and animal body and 
4. Possible health impacts on animals and humans due to over exposure.

\subsection{Medical Geology: the re-emerging discipline and its role in addressing environmental health consequences.}

Medical Geology is a discipline in geoscience working in tandem with medical/health workers that deals with the impacts of geologic materials and processes whose influence on the natural environment impact animal and human health (Finkelman et al., 2003; Selinus et al., 2010). Its main concern is to solve a wide range of environmental health problems. It does so by bringing together geoscientists and medical/public health researchers to address health problems caused by geologic materials and the processes distributing and concentrating trace elements in rocks, minerals, water, and indirectly into food crops. The impact of naturally occurring geological processes on public health by virtue of how high or how low animals and humans have been exposed to either essential or toxic elements have adverse consequences. The relationship between geologic materials enriching and depleting trace elements concentrations in rocks, soils, water, minerals, natural dust in the atmosphere and indirectly in food and human health has been known for centuries (Selinus, 2004). This relatively makes medical geology not strictly an emerging discipline but rather a re-emerging discipline. Confirmation that medical geology is an old discipline is documented in Ancient Chinese, Egyptian, Islamic, and Greek texts which describe the many therapeutic applications of various rocks and minerals in the treatment of many ailments and diseases. Chinese texts from more than 2,000 years ago describe 46 different minerals that were used for medicinal purposes. It is very common in the traditional Ghanaian setting for lactating and pregnant women to eat clay balls to provide supplemental minerals that they may be lacking in their diet. Others also consumed the earthy clay material to adsorb toxic secondary compounds widely distributed in plant foods and additionally to protect the gastrointestinal tract from chemical and biological abuse and above all to counter gastrointestinal disease (Arhin et al., 2016). These practises have been passed on from older generations and are still practised to date.

The prime responsibilities of practitioners of Medical Geology are: 
1. To identify geochemical anomalies in soil and water that may affect human/animal health.

2. To identify the environmental causes of known health problems and, in collaboration with biomedical/public health researchers, seek solutions to prevent or minimize these problems.

3. To evaluate the beneficial health effects of geologic materials and process.

4. To reassure the public when there are environmental health concerns regarding geologic materials or processes.

5. To forge links between developed and developing countries to find solutions for environmental health problems.

Among the environmental health problems that medical geology practitioners are working with the medical community to address are: exposure to toxic levels of trace essential and nonessential elements such as arsenic and mercury; trace element deficiencies of the essential elements; exposure to natural dusts and radioactivity; naturally occurring organic compounds in drinking water and volcanic emissions amongst others. It is the related health issues that spring up from these geologic processes that medical geology intends to address through collaborative research with the medical health community. This collaboration will help to model pollution dispersion in surface and ground waters and can be applied in monitoring industrial pollution and its associated health problems. These models will facilitate the identification of the pollution hotspots by the medical geologists and enable the medical researchers to come up with correct medication to treat the associated diseases.

\subsection{Current status of Medical Geology in Ghana}

Medical geology is an old discipline in geoscience except its application in Ghana has not been publicised or it is used without understanding the science undertone. In rural Ghana and some urban centres in Ghana some people practice geophagy, the act of eating earthy material for healing purpose. They do so believing that the medicinal properties in the earthy material can protect and provide supplemental minerals that may be lacking in their regular diet. Others also consume clay material to adsorb any secondary toxic compounds widely distributed in the raw plant foods that they eat. Additionally, some apply or eat the geologic materials to protect the gastrointestinal tract from chemical and biological abuse and thus avoid gastrointestinal diseases. All these are based on beliefs. Hippocrates (460-377 B.C) and Aristotle were the first 
to recognize the relationship between human diseases and the earth's elements. There are so many studies that researchers in Ghana have carried out on trace element geochemistry, but the conclusions generally are decoupled from geological processes and materials. Nonetheless this is not to say that there are no medical geology related researchers in Ghana. There are a couple of authors who have published in the field of medical geology research (Arhin et al; Arhin et al., 2016; Arhin and Kazapoe, 2017; Arhin and Zango, 2016; Arhin et al., 2016; Craig et al., 2015) but these authors think the effort to address environmental health problems should be nationalistic and that a national survey that will develop a geochemical atlas will significantly contribute in the identification of geographic locations with excess toxic and essential element concentrations

\subsection{Geological processes impacting on the natural environment and consequences on Public Health}

Many diseases from a medical doctor's perspective are due to a lack of some essential nutrients or trace elements in humans and animals. The sources of these trace elements are linked to the underlying rocks which vary across the geographical space. This explains the wide range of geochemical variations and hence different disease patterns. Quoting Paracelsus (1493-1541) 'All substances are poisons; there is none which is not a poison. The right dose differentiates a poison and a remedy'. The current illicit mining menace popularly known in Ghana as 'Galamsey Menace' has drawn the attention of the population to the land degradation and pollution of water bodies. But there are more fearful issues that we ought to be concerned about the impact of the natural environment on the ecosystem and health.

In Ghana environmental health problems arising from the interactions with the natural environment have not been publicised much but there are archival reports that suggests prevalence of environmental pollutions particularly in the mining environments, but the reports fail to link the so-called pollutants to their possible health consequences. Exacerbating this is that fact that the geologically related health issues are strongly aggravated by other factors such as poverty and malnutrition in these localities. The quandary particularly in Ghana is that the medical geology research is in its infancy stage and the health data inventory has not been analysed in a way that health outcomes could be correlated with geographical locations. There are significant body of knowledge for the halogens (example fluorine in soils and drinking water is causing dental fluorosis in Bongo District (Arhin and Zango, 2016; Apambire et al., 1997) and iodine whose deficiency results in risk of infant mortality, miscarriages and goitre 
especially in the Upper West of Ghana-Health News (mobile.ghanaweb.com 2009). Another set of elements that have seen some investigations particularly in mining areas are arsenic, silicon and a small number of trace metals. The distributions and concentrations of these trace elements in these environments do not show any meaningful correlations between geochemistry and epidemiology because the data interpretations were hampered by the use of non-multidisciplinary approaches. There are many trained geoscientists in Ghana but there are not enough trained personnel for these types of analyses that involved geology, geochemistry and medicine. The national healthcare cost that is skyrocketing. Indeed, many of the leading causes of death and many of the unexplained deaths at the health centres in Ghana could be linked to impacts of natural environment (Table 1) on health, which have been ignored by the health ministry and instead of the geoscientists advocating for inter-disciplinary research to help in the national developments they have been silent due to lack of expertise in this area of geology. Water hardness has been implicated in some forms of cardiovascular disorders (Leary, 1986; Derry et al., 1990) which the medical geologists can identify for early mitigation processes to be adopted. The Birimian of Ghana has undergone two stages of Eburnean orogenic episodes and several styles of mineralisation dating as far back as the Proterozoic. Considerable quantities of elements, both essential and toxic, that were involved the Eburnean events and in ore forming processes, have been released into the environment, either by later geological processes (e.g. weathering, leaching and eluviation) or by mining and oreprocessing operations. The Birimian of Ghana host chalcophile elements such as $\mathrm{Pb}, \mathrm{As}, \mathrm{Cd}$ and $\mathrm{Hg}$ (Kesse, 1980; Arhin et al., 2016) particularly in terrains that host gold mineralisation. The ore-processors also use $\mathrm{Hg}$ in their gold extraction though the use of $\mathrm{Hg}$ was prohibited in 1950 but there has been an upsurge of it by the illicit miners currently. Elevated levels of these trace elements and other potential pollutants have been recorded in many mining and cultivated lands. (Arhin et al., 2016) carried out studies on the Birimian of Talensi District and found geogenic contaminants to include $\mathrm{As}$ and $\mathrm{Pb}$ whereas $\mathrm{Hg}$ was identified to have been introduced in the environment during the ore-processing stages of gold extraction. All these trace elements depending on degree of exposure and pathways have health consequences to humans and animals and their distributions and concentrations must be known and correlated with the disease pattern map for environmental health remedies. Apambire et al. (1997) and Craig et al. (2015) report of high levels of fluoride in drinking waters in Bongo district of Ghana. Evidence of dental fluorosis and dental caries is common disease and occur predominantly in microclinerich-granitoids areas. Spatial distribution and concentrations and their correlations with fluorosis are yet to be examined. (Smedley et al., 1996) also report of high level As in 
groundwater at Obuasi in Ashanti Region and also in Bolgatanga in the Upper East Region of Ghana. They expressed the health problems related to groundwater in these two areas. Reports in the media about the upsurge of suicides in Ghana are alarming of which the mental health workers and the government are seeking for solutions. Most of the drugs administered to patients with any form of mental health are lithium-based. This element lithium (Li) is ubiquitous in all rocks. Lithium ingestion is known to control the act of committing suicide (Ohgami et al., 2009) Investigations in the USA and Austria confirm the inverse relationship of lithium concentrations in drinking water and suicide. It appears dietary-lithium may be able to address some of the mental health issues that had led to suicide rates without going through any complex medical treatment. The only thing without which life is unbearable is water. Currently the plan should be towards prevention; therefore, geospatial examination of lithium in drinking water may provide information on lithium concentrations. This should be the fundamental thing to do in order to define areas prone to likely mental health disorders grading to suicides if not checked and mitigated. The same way that iodine is added to salt to address iodine deficiency disorders (IDD); the same can be applied here by adding some amounts of Li in drinking water after problem areas have been identified. Medical doctors can identify trace element deficiencies and/or toxicities which are as a result of geological conditions. Moving forward attention is required to allow medical geologists work in tandem with medical workers and with the politicians for suitable environmental and economic policies that has a link with the earth and the environment.

There is a significant knowledge about functions of iron and calcium to human health. But very little is known about magnesium $(\mathrm{Mg})$, the mineral that plays a crucial role to human health. It is involved in over 300 of the body's regulatory and biochemical systems. Magnesium is so important to so many functions that the impact of low levels spans all areas of health. The source of this element is geogenic. Plants and all food crops absorbed them from the soils; animals ingested them and as we eat the food and the animals we obtain our portion of the miracle mineral $\mathrm{Mg}$. Groundwater aquifers and the surface waters take up fractions of $\mathrm{Mg}$ in rocks that host them. As it is commonly said that $\mathrm{Ca}$ is useful for building strong bones and teeth; Fe for the treatment of anaemia but nothing for $\mathrm{Mg}$. Excess amount of $\mathrm{Ca}$ in the blood vessels causes blockage and to free up the blockage we need $\mathrm{Mg}$ to dissolve the $\mathrm{Ca}$. It is no wonder that $\mathrm{Mg}$ deficiency may lead to heart conditions, blood pressure, cancer, chronic pain, digestion problems and diabetes etc. The non-existence of inter- and transdisciplinary research involving medical geologist, medical and public health workers, agriculturist, environmental 
scientist, civil engineers, pathologist, toxicologist and social scientist may not help in our national development.

\subsection{Conclusions}

A major challenge for effective health care delivery in developing countries is a lack of data linking the geology to the various health challenges associated with geological processes which could play a crucial role in identifying some of the causes of many of the emerging diseases. The evolution of the geology of Ghana coupled with the numerous anthropogenic and geogenic activities adding up to the geochemical background values of elements has been identified to have an effect on the natural environment and consequently affect the public Health which implicitly affects the wellbeing and the socio-economics of its populace. Fluoride, which occurs in excessive concentrations in some parts of the Upper East Region of the country, is associated with such health issues as dental carries and skeletal fluorosis. Iodine deficiency has also been suggested as a possible cause of miscarriages and goitre in the Upper West Region of Ghana. The dust carried by the Northeast trade winds during the harmattan season is also associated with respiratory infections. Research has also shown a strong correlation between some forms of cardiovascular disorders and water hardness. High levels of Arsenic registered in Obuasi, a town in the Ashanti Region of Ghana, is also associated with cancer, kidney and bladder diseases and skin lessons.

The re-emergence of the discipline of medical geology provides an avenue to bridge this gap. As has been shown in this review, some research exists in Ghana which takes into consideration the distribution of minerals and their impact on health, but there is a clear lack of any effort to discuss this in terms of the spatio-temporal distribution of geologically associated diseases and public health. Broadening our understanding of medical geology could help devise problemsolving techniques as well as an appropriate therapy in preventing many geological related health issues and thus improve life quality and bring national development in Ghana.

\section{References}

Abitty, E. K., Dampare, S. B., Nude, P. M., \& Asiedu, D. K. (2016). Geochemistry and petrogenesis of the K-rich 'Bongo-type'granitoids in the Paleoproterozoic Bole-Nangodi greenstone belt of Ghana. Journal of African Earth Sciences, 122, 47-62. 
Alloway, B. J. Ed., Heavy Metals in Soils: Trace Metals and Metalloids in Soils and Their Bioavailability, Springer, Amsterdam, The Netherlands, 3rd edition, 2013.

Apambire, W. B., Boyle, D. R., \& Michel, F. A. (1997). Geochemistry, genesis, and health implications of fluoriferous groundwaters in the upper regions of Ghana. Environmental Geology, 33(1), 13-24.

Arhin, E. and Kazapoe, R. (2017). Selenium in Locally Produced Food Crops and Implications on Healthy Eating: A Case Study at the Talensi District of Ghana. EC Nutrition 8.3 (2017): 85-92.

Arhin, E., and Zango M. S. 2016. Impact of trace elements in the natural environment and public health: a medical geology perspective. Ann. Public Health Res., 3(4): 1051

Arhin, E., and Zango M. S. 2016. Impact of trace elements in the natural environment and public health: a medical geology perspective. Ann. Public Health Res., 3(4): 1051

Arhin, E., Boansi, A. O., and Zango, M. S. 2015. Trace elements distributions at Datoko-Shega artisanal mining site, northern Ghana. Environmental Geochemistry and Health, vol. 37, no 2, ISSN: 0269-4042, DOI 10.1007/s 10653-10653-015-9705-0, Springer.

Arhin, E., Boansi, A. O., and Zango, M. S. 2015. Trace elements distributions at Datoko-Shega artisanal mining site, northern Ghana. Environmental Geochemistry and Health, vol. 37, no 2, ISSN: 0269-4042, DOI 10.1007/s 10653-10653-015-9705-0, Springer.

Arhin, E., Kazapoe R. and Zango M. S. 2017. The hidden dangers of unknowingly ingesting harmful trace elements from food crops and their health implications: a case study at Talensi District in the Upper East Region, Ghana. EC Nutrition, 7 (1), p. 34-45.

Arhin, E., Kazapoe R. and Zango M. S. 2017. The hidden dangers of unknowingly ingesting harmful trace elements from food crops and their health implications: a case study at Talensi District in the Upper East Region, Ghana. EC Nutrition, 7 (1), p. 34-45.

Arhin, E., Zango, M.S. and Berdie, B. S. 2016. Geochemical background of some potentially toxic and essential trace elements in soils at the Nadowli District of the Upper West Region of Ghana. Journal of Earth, Environment and Health Sciences. 2(2) p.56-65. Wolters-Kluwer-Medknow publishers, Doi: 10.4103/2423-7752422. 
Arhin, E., Zango, M.S. and Berdie, B. S. 2016. Geochemical background of some potentially toxic and essential trace elements in soils at the Nadowli District of the Upper West Region of Ghana. Journal of Earth, Environment and Health Sciences. 2(2) p.56-65. Wolters-Kluwer-Medknow publishers, Doi: 10.4103/2423-7752422.

Armah, F. A. Kuitunen, M. Luginaah, I. and Mkandawire, P. (2012). Non occupational health risk assessment from exposure to chemical contaminants in the gold mining environment of Tarkwa, Ghana, Trends in Applied Sciences Research, vol. 7, pp. 181-195, 2012.

Bempah, C. K., Ewusi, A., Obiri-Yeboah, S., Asabere, S. B., Mensah, F., Boateng, J., \& Voigt, H. J. (2013). Distribution of arsenic and heavy metals from mine tailings dams at Obuasi Municipality of Ghana. American Journal of Engineering Research, 2(5), 61-70.

Craig, L., Lutz, A., Berry, K. A., \& Yang, W. (2015). Recommendations for fluoride limits in drinking water based on estimated daily fluoride intake in the Upper East Region, Ghana. Science of the Total Environment, 532, 127-137.

Dampare, S. B., Shibata, T., Asiedu, D. K., Osae, S., \& Banoeng-Yakubo, B. (2008). Geochemistry of Paleoproterozoic metavolcanic rocks from the southern Ashanti volcanic belt, Ghana: Petrogenetic and tectonic setting implications. Precambrian Research, 162(3), 403-423.

Derry C.W., Bourne D.E., Sayed A.R., (1990). The relationship between the hardness of treated water and cardiovascular disease mortality in South African Urban areas. South African Med. J. 7(10): 522-524

Dzigbodi-Adjimah, K. (1993). Geology and geochemical patterns of the Birimian gold deposits, Ghana, West Africa. Journal of geochemical exploration, 47(1-3), 305-320.

Finkelman, R. B., Belkin, H. E., Centeno, J. A., \& Zheng, B. S. (2003). Geological epidemiology: coal combustion in China. Geology and Health: Closing the Gap (Skinner HC, Berger AR, eds). Oxford: Oxford University Press, 45-50.

Ghana Statistical Service, (2012). Population and housing census, summary report of final result. Retrieved from the statistical service (2012). http://statsghana. gov.gh/docfiles/2010phc/Census2010_Summary_report_of_final_results.pdf. 
Ghana Statistical Service, (2012). Population and housing census, summary report of final result. Retrieved from the statistical service (2012). http://statsghana. gov.gh/docfiles/2010phc/Census2010_Summary_report_of_final_results.pdf.

Griffis, J., Barning, K., Agezo, F. L., and Akosa, F., (2002). Gold deposits of Ghana, prepared on behalf of Ghana Mineral Commission, Accra, Ghana, 432 p.

Kesse, 1980, G. O. (1985). The mineral and rock resources of Ghana: A. A. Balkema Press, Rotterdam, Netherlands, 610 p.

Leary W. P (1985). Content of magnesium in drinking water and deaths fro ischemic heart disease in white South Africans. Magnesiu 5 :150-153

Leube, A, Hirdes, W., Mauer, R., and Kesse, 1980, G. O., 1990. The early Proterozoic Birimian Super group of Ghana and some aspects of its associated gold. Precambrian Research, vol. 46(1-2), p. 139-165.

Nguyen, H. L. Leermakers, M. Osán, J. Török, S. and Baeyens, W. (2005). Heavy metals in Lake Balaton: water column, suspended matter, sediment and biota, Science of the Total Environment, vol. 340, no. 1-3, pp. 213-230, 2005.

Norman, D. I, Miller, G. P, Branvold, T., Thomas, H., Appiah, J, Ayamsegna, J., Nartey R. Arsenic in Ghana, West Africa, Groundwater (Abstract). USGS Science of the changing world. https://wwwbrr.cr.usgs.gov/projectsOhgami, H., Terao, T., Shiotsuki, I., Ishii, N., \& Iwata, N. (2009). Lithium levels in drinking water and risk of suicide. The British Journal of Psychiatry, 194(5), 464-465.

Nude, P. M., Kwayisi, D., Taki, N. A., Kutu, J. M., Anani, C. Y., Banoeng-Yakubo, B., \& Asiedu, D. K. (2015). Petrography and chemical evidence for multi-stage emplacement of western Buem volcanic rocks in the Dahomeyide orogenic belt, southeastern Ghana, West Africa. Journal of African Earth Sciences, 112, 314-327.

Selinus, O. (2004). Medical Geology: an emerging speciality. Terrae, 1(1), A1-A8.

Selinus, O., Alloway B., Centeno J. A., Finkelman, R. B., Fuge, R., Lindh, U and Smedley P. (2005). Essentials of Medical Geology: impacts of the natural environment on Public Health, Elsevier academic press, 812 pp. ISBN: 0-12- 636341-2. 
Simeonov, V., Stratis, J. A. and Samara C. (2003). Assessment of the surface water quality in Northern Greece, Water Research, vol. 37, no. 17, pp. 4119-4124, 2003.

Simeonov, V., Stratis, J. A. and Samara C. (2003). Assessment of the surface water quality in Northern Greece, Water Research, vol. 37, no. 17, pp. 4119-4124, 2003.

Smedley, P. L., \& Kinniburgh, D. G. (2002). A review of the source, behaviour and distribution of arsenic in natural waters. Applied geochemistry, 17(5), 517-568.

Smedley, P.L., Edmunds, W.M. \& Pelig-Ba, K.B. (1996). Mobility of arsenic in groundwater in the Obuasi area of Ghana. In: Appleton, J.D., Fuge, R., McCall, G.J.H. (Eds.), Environmental Geochemistry and Health, Geological Society Special Publication.113. Geological Society, London, pp. 163-181.

Tecsult, (1999). Etude de faisibilite' de projet de production d'or desgites aurife'res de Koupe 'la-Nagse'ne'-Nongfarre' (Provinces du Bam, du Passore' et du Yatenga). Phase d'exploration. Tecsult International Limite'e, Ouagadougou. 